\title{
From "the Black O'Connell" to "the Black Douglas"
}

\author{
Alasdair Pettinger \\ Independent Scholar
}

Like many other touring performers, Frederick Douglass connected with his audiences by declaring some kind of affiliation with the places he visited. He usually did this by demonstrating his knowledge of figures of local or national importance whom he had reason to admire. In this article I will consider some examples from his speaking engagements in Ireland and Scotland in 1845-46. My particular interest here is the ways in which Douglass not only paid tribute to certain historical and contemporary Irishmen and Scotsmen (such as Daniel O'Connell and Robert Burns) but came to be endowed with their names — whether he liked it or not — as if he were no more than an African American version of themselves. That he was dubbed "the Black O'Connell" has become almost proverbial. Cornered by such moves, Douglass tended to respond with a diplomatic silence. But they may also have alerted him to the possibility of exploiting the historical resonance of his own adopted name by tentatively identifying himself as "the Black Douglas" after the medieval Scottish warlord. In following the choices Douglass makes, we can see him experimenting with different rhetorical alter egos that serve his emerging ambition to be seen as a representative or leader of a people.

In his first autobiography, Narrative of the Life of Frederick Douglass, An American Slave, Douglass writes of the importance to him as a young man of reading the Columbian Orator, a widely reprinted primer in the "arts of eloquence," singling out two texts in particular, including "one of Sheridan's mighty speeches on and in behalf of Catholic emancipation." As it happens, he confuses Richard Brinsley Sheridan with another Irishman, Arthur O'Connor, who is correctly identified as the author of the speech by the editor of the Orator, Caleb Bingham. ${ }^{2}$ Douglass only once referred to O'Connor's speech in his lectures in Ireland. ${ }^{3}$ But he did take care on at least two occasions, when giving an account of the disturbances on his voyage departing from Boston, to let audiences know that one of those who defended him against the physical threats of a pro-slavery passenger was a "noble hearted Irishman. A Mr Gough, who told the reckless trafficker in human flesh and bones that 'Two could play at that work.' "4 This was Captain Thomas Bunbury Gough, returning home on leave from his infantry regiment in Canada. There is a memorial to him in St

\footnotetext{
${ }^{1}$ Frederick Douglass, Narrative of the Life of Frederick Douglass, an American Slave, Written by Himself [1845], in John W. Blassingame, John R. McKivigan, and Peter P. Hinks, eds., The Frederick Douglass Papers, Series 2: Autobiographical Writings, 3 vols. (New Haven, Conn.: Yale University Press, 1999), 1:35.

${ }^{2}$ For a detailed discussion of O'Connor's speech and Douglass's response to it, see Ann Coughlan, "Frederick Douglass and Ireland, 1845: The 'Vertiginous Twist(s) of an Irish Encounter' " (PhD diss., University College Cork, 2015), 17-71.

${ }^{3}$ Dublin Evening Mail, 1 October 1845 and London Standard, 1 October 1845. Douglass makes no other reference to Sheridan or O'Connor in any of the newspaper reports of his speeches in Ireland in 1845-46, usefully collected in Christine Kinealy, ed., Frederick Douglass and Ireland: In His Own Words, 2 vols. (London: Routledge, 2018).

${ }^{4}$ Freeman's Journal, 13 September 1845. See also John W. Blassingame, ed., The Frederick Douglass Papers, Series 1: Speeches, Debates, and Interviews, 5 vols. (New Haven, Conn.: Yale University Press, 1979), 1:91.
} 
Columb's Cathedral in Derry, commemorating his death in battle in the Crimean War ten years later. $^{5}$

Much more important, though, are Douglass's expressions of praise for Daniel O'Connell. Within a month of his arrival in Dublin, Douglass got the chance to hear the elderly politician speak at the Repeal movement's new headquarters, Conciliation Hall. The account of the occasion Douglass sent to William Lloyd Garrison dwells on the impact of his oratory: "I have never heard one, by whom I was more completely captivated than by Mr O'Connell," he writes. ${ }^{6}$ Douglass in 1845 represents his own formation as an orator as if one Irishman, O'Connor, gave him his first lessons in public speaking on the printed page, while another, O'Connell, followed it with a practical demonstration from the lecture platform.

But it is O'Connell's bold stance against slavery that animates most of Douglass's invocations in his subsequent speeches. In Cork, for example, he says, "I feel grateful to him, for his voice has made American slavery shake to its centre.- I am determined wherever I go, and whatever position I may fill, to speak with grateful emotions of Mr O'Connell's labours."7 And indeed, he honored his pledge, continuing to praise the man and inviting others to follow his example throughout the rest of his tour. For instance, in Newcastle-upon-Tyne, he applauds O'Connell's commitment to refuse the "blood-stained offerings" from pro-slavery supporters in the United States. ${ }^{8}$ In Exeter, Douglass repeats his conviction that "O'Connell was the friend of the negro."9 And he cites O'Connell- "no matter for my illustration, how truly or falsely"employing the image of "the track of a wounded man through a crowd" in his farewell address in London in March 1847. ${ }^{10}$

Still, despite his immense popularity, O’Connell was a controversial figure. If Douglass was happy to praise his abolitionism, he tended to avoid directly endorsing his stance on Repeal. ${ }^{11}$ Even at Conciliation Hall, he realizes "he would not be expected to speak of Repeal as a political question." And if Douglass goes on to break his own rule, he takes care to avoid doing so in his own name: "The spirit that animated those whom he then addressed had a kindred spirit in America, and thousands there who hated slavery were devoted to the cause of Ireland (cheers).

\footnotetext{
5 “Colonel Thomas Bunbury Gough,” War Memorials Online, www.warmemorialsonline.org.uk/memorial/245094.

${ }^{6}$ Frederick Douglass to William Lloyd Garrison, Dublin, 29 September 1845, in John R. McKivigan, ed., The Frederick Douglass Papers, Series 3: Correspondence, 2 vols. (New Haven, Conn.: Yale University Press, 2009-), $1: 57$.

${ }^{7}$ Blassingame, Douglass Papers, ser. 1, 1:45.

${ }^{8}$ Blassingame, Douglass Papers, ser. 1, 1:337-38. In April 1844 a letter from the American and Foreign Anti-Slavery Society to the Free Church of Scotland cited O'Connell's refusal in their condemnation of that Church's fund-raising trip to the United States: Letter from the Executive Committee of the American and Foreign Anti-Slavery Society to the Commissioners of the Free Church of Scotland (Edinburgh, Scot.: Myles Macphail, [1844]), 8. This suggests that he may have inspired the "Send Back the Money" campaign in Scotland, started, almost single-handedly, by Henry Clarke Wright, who coined the slogan at a meeting of the Glasgow Emancipation Society in November 1844 and lectured frequently on the issue from March 1845, until Douglass, James Buffum and George Thompson joined him in early 1846. See also Douglas C. Riach, "Daniel O'Connell and American Anti-Slavery," Irish Historical Studies 20, no. 77 (1976): 15n; Alasdair Pettinger, Frederick Douglass and Scotland, 1846: Living an Antislavery Life (Edinburgh, Scot.: Edinburgh University Press, 2019), 50-51, 62n19.

${ }^{9}$ Blassingame, Douglass Papers, ser. 1, 1:352.

${ }^{10}$ Blassingame, Douglass Papers, ser. 1, 2:27.

${ }^{11}$ Fionnghuala Sweeney, Frederick Douglass and the Atlantic World (Liverpool, Eng.: Liverpool University Press, 2007), 28n24; Tom Chaffin, Giant's Causeway: Frederick Douglass's Irish Odyssey and the Making of an American Visionary (Charlottesville, Va.: University of Virginia Press, 2014), 105, 189; Laurence Fenton, Frederick Douglass in Ireland: "The Black O'Connell" (Cork, Ire.: The Collins Press, 2014), 165.
} 
They said that they would be Repealers if they were in Ireland (hear)." 12 Douglass would have known that some of his audiences, especially in Belfast, would have been decidedly hostile to Repeal, but his host in Dublin, Richard Webb, who did not support Repeal, may have advised him to steer clear of the matter in any case. ${ }^{13}$

Furthermore, within the Repeal movement, O'Connell was increasingly under fire from a younger, more radical generation ("Young Ireland") who were to break away the following year. ${ }^{14}$ Douglass may also have been aware of Chartists' hostility to O'Connell, especially in the West of Scotland, after his denunciation of the Glasgow cotton spinners' strike in $1837 .{ }^{15}$ Even as an abolitionist, O'Connell's reputation was not unsullied; Garrison thought that his support of antislavery wavered in the face of the levels of support for Repeal among the pro-slavery Irish in the United States. ${ }^{16}$ It was only under pressure from James Haughton that O'Connell took the stand against their "blood-stained" donations, and there is little evidence that he afterwards actually returned those he received. ${ }^{17}$ If Douglass held firm to an antislavery O'Connell well after his departure from Ireland, he must have found his public affiliation with "The Liberator" awkward and requiring some tact, given that not all those who were warm to his abolitionist message shared Douglass's enthusiasm for the man.

In Cork he pauses in a lecture to remark: "I cannot proceed without alluding to the man who did much to abolish slavery. I mean Daniel O'Connell." 18 A few months later in Ayr, needing a Scottish hero to draw to his side, Douglass rewinds the tape, as it were, and begins again, this time choosing someone more locally connected. Using an almost identical formulation (allowing for the shift to indirect speech in the newspaper report), he declares that "he was proud of having been in the land of him who had spoken out so nobly against the oppressions and wrongs of slavery-he alluded, of course, to Robert Burns." 19

Douglass spoke and wrote about Burns much more often than he did about O'Connell. The first book he purchased after his flight from Maryland was James Currie's The Works of Robert Burns, which he later passed on to his eldest son, Lewis. ${ }^{20} \mathrm{He}$ regularly cited the poet, most extensively in a letter he wrote from Ayr about his visit to Burns's sister Isabella, who still lived

\footnotetext{
${ }^{12}$ Freeman's Journal, 30 September 1845. In Newcastle, he similarly tempered his praise for O'Connell, warning that "I am not here to indorse Mr. O'Connell or his agitation.” Blassingame, Douglass Papers, ser. 1, 1:337.

${ }^{13}$ On Webb's attitude to O'Connell and Repeal see Fenton, Frederick Douglass in Ireland, 92; Christine Kinealy, Daniel O'Connell and the Anti-Slavery Movement: "The Saddest People the Sun Sees" (London: Pickering \& Chatto, 2011), 125; Riach, "Daniel O’Connell," 9; Douglas C. Riach, "Richard Davis Webb and Antislavery in Ireland," in Antislavery Reconsidered: New Perspectives on the Abolitionists, ed. Lewis Perry and Michael Fellman (Baton Rouge: Louisiana State University Press, 1979), 164-65.

${ }^{14}$ See Chaffin, Giant's Causeway, 58-60; Kinealy, Daniel O'Connell, 130-33, 137-38.

${ }^{15}$ See Alexander Wilson, The Chartist Movement in Scotland (Manchester, Eng.: Manchester University Press, 1970), 143; W. Hamish Fraser, Chartism in Scotland (Pontypool, Wales: Merlin Press, 2001), 30, 95, 194.

${ }^{16}$ See esp. Riach, "Daniel O'Connell," 3-25; also Kinealy, Daniel O'Connell, 114-15, 124-25; Chaffin, Giant's Causeway, 66; John F. Quinn, “'Safe in Old Ireland': Frederick Douglass's Tour, 1845-1846,” The Historian 64, no. 3/4: 539-40.

${ }^{17}$ Lee Jenkins, “ ‘The Black O'Connell': Frederick Douglass and Ireland,” Nineteenth Century Studies no. 13 (1999): 40n14; Fenton, Frederick Douglass, 94; Kinealy, Daniel O'Connell, 113-15.

${ }^{18}$ Blassingame, Douglass Papers, ser. 1, 1:45.

${ }^{19}$ Ayr Observer, 31 March 1846.

20 The University of Rochester River Campus Libraries' Department of Rare Books, Special Collections, and Preservations has Douglass's copy of this edition, which is inscribed: "This book was the first bought by me after my escape from slavery. I have owned it nearly thirty one years and now give it to my oldest son as a keep sake. F.D." www.rbscp.lib.rochester.edu/4646.
} 
nearby. ${ }^{21}$ Three years later he addressed a Burns Supper in Rochester, New York, defending his right to do so, "though I am not a Scotchman and have a coloured skin": "but if a warm love of Scotch character - a high appreciation of Scotch genius - constitutes any of the qualities of a true Scotch heart, then indeed does a Scotch heart throb beneath these ribs."22 In both Cork and Ayr the attribution of abolitionist sympathies is extravagant, given that the priorities of both O'Connell and Burns lay elsewhere. It has proven difficult to find from Burns any unqualified statement in support of the antislavery agitation that flourished during his final years, and much has been made of his plans (seriously entertained or not) to take on a job as overseer on a Jamaican plantation before the success of his first volume of poems persuaded him to stay in Scotland. ${ }^{23}$ But Burns, in addition to being conveniently dead, was venerated more universally by his compatriots than O'Connell. Political divisions in Ireland were expressed as for or against O'Connell. In Scotland, by contrast, everyone claimed Burns; they just adapted him to suit their various, and often opposed, purposes. There was a Tory Burns, a Whig Burns, a Chartist Burns and so on.

\section{II}

If Douglass himself took the initiative to affirm a kind of intellectual or political affiliation to local heroes through a shrewd invocation of their names, others made similar connections on his behalf. For example, the church minister who welcomed him to Dundee, George Gilfillan, later referred to Douglass as "the Burns of the African race." ${ }^{24}$ Gilfillan himself might have felt justified in doing so, as merely echoing Douglass's own admiration for Burns, but such a move, made in Douglass's absence and without his consent, figures the relationship between them in quite a different way. More significantly, while Douglass expresses a certain connection with Burns, as one among many other famous figures who impress or inspire him, Gilfillan identifies Douglass as Burns, inviting his readers to consider certain implied attributes of the poet (his command of language, perhaps, or his rise from rural obscurity to international renown) as those which uniquely define the antislavery campaigner's whole being.

"The Burns of the African race" is an example of what students of rhetoric call antonomasia, the substitution of a proper noun for a common noun denoting qualities associated with the historic bearer of that name. Thus, someone might be referred to as "a little Hitler" or "some modern Robespierre" or "the next Einstein." 25 The figure relies heavily on a shared understanding with the audience, who is assumed to not only know who the named person is, but also which of their characteristics are being brought into play. But this does not prevent it from being controversial, for antonomasia is especially vulnerable to criticism that it relies on a comparison that is inappropriate or even offensive. In particular, structures of power dictate who gets compared to whom, and to what extent the relationship is reversible. For antonomasia frequently reinforces dominant standards of description and assessment, a point well made by

\footnotetext{
${ }^{21}$ Frederick Douglass to Abigail Mott, Ayr, 23 March 1846, in McKivigan, Douglass Papers, ser. 3, 1:111-12. For further discussion of the letter see Pettinger, Frederick Douglas and Scotland, 151-55.

22 J[ohn] D[ick], “Burns' Anniversary Festival," North Star, 2 February 1849. For further discussion of the event see Pettinger, Frederick Douglass and Scotland, 156-64.

${ }^{23}$ See Pettinger, Frederick Douglass and Scotland, 135-50.

${ }^{24}$ Dundee, Perth and Cupar Advertiser, 24 January 1851.

${ }^{25}$ Antonomasia can also refer to the substitution of a common noun for a proper, as when Daniel O'Connell is called "The Liberator," but it is the other form that largely concerns us here. For a good discussion of antonomasia of the proper noun see Sarah Leroy, “Quels fonctionnements discursifs pour l'antonomase du nom propre?" Cahiers de praxématique no. 35 (2000): 87-113.
} 
Mona Eltahawy, responding to a phrase that appeared in several tributes to Nawal El Saadawi after her death in 2021: "I am enraged that some refer to Nawal as the "Simone de Beauvoir of the Arab world." Do not call her that. She is the Nawal El Saadawi of the world. We are not local versions of white feminists." 26 Such a figurative use of a proper name may be fuelled by good intentionsthe speaker implying that $\mathrm{A}$ is worthy of comparison to $\mathrm{B}$, perhaps even destined to surpass them in fame. Sometimes, though, the comparison may be seen as excessive - perhaps deliberately soand signify rather that A could never match the ideal represented by B. Either way, prevailing norms - such as Whiteness - are often reinforced, as Eltahawy underscores.

Among African American contemporaries of Douglass who also toured Europe, the actor Mary Webb, for example, was known as the "coloured Siddons," after the better-known White performer Sarah Siddons. ${ }^{27}$ And in a slightly more convoluted form of antonomasia that makes the substitution in two steps, the singer Elizabeth Greenfield was dubbed the "black Swan" in a revision of Jenny Lind's nickname, "the Swedish nightingale." ${ }^{28}$ Later, Harriet Tubman became known as "the Moses of her people," one of many leaders of African descent to earn the moniker "Black Moses," including Marcus Garvey and Jomo Kenyatta. ${ }^{29}$ The subjects of such renamings rarely have any say over the matter. Gilfillan's remark was made several years after Douglass's departure from Scotland in an article he may never have read. But in Dublin in 1845 Douglass actively invited an association between himself and another figure at an event in which he spoke. The circumstances bear examination.

When O'Connell invited Douglass to address the audience at Conciliation Hall, Douglass told them: "The poor trampled slave of Carolina had heard the name of the Liberator with joy and hope, and he himself had heard the wish that some black O'Connell would yet rise up amongst his countrymen, and cry, 'Agitate, agitate, agitate." "30 $\mathrm{He}$ was referring to a public meeting in Glasgow ten years earlier at which O'Connell famously expressed (to great cheers) the hope that one day "some black O'Connell might rise among his fellow slaves, who would cry, agitate, agitate, agitate." 31 Douglass's testimony suggests that O'Connell's words travelled far and wide. But he would have known that in quoting them he was not only paying tribute to the transatlantic reach of O'Connell's reputation, stretching beyond the Irish diaspora, he was also tempting the audience to imagine that Douglass himself was - or one day would be - the leader O'Connell had wished for. Many years later Douglass recalled that O'Connell himself spelled it out for them, claiming that at the meeting he "playfully called me the 'Black O'Connell of the United States." "32 Whether this was true or not-and newspaper reports of the occasion simply noted that he "introduced to the meeting Mr. Douglas, who had been an American slave" (a more striking introduction would surely have been mentioned) - Douglass did nothing at the time to repudiate the fantasy of himself as a redeemer formed in the Irish leader's image. ${ }^{33}$

\footnotetext{
${ }^{26}$ Mona Eltahawy, “A Savage and Dangerous Woman: Nawal El Saadawi,” Feminist Giant no. 28 , March 2021. www.feministgiant.com/p/essay-nawal-el-saadawis-savage-and.

${ }^{27}$ Lisa Merrill, “'Most Fitting Companions': Making Mixed-Race Bodies Visible in Antebellum Public Spaces,” Theatre Survey 56, no. 2 (2015): 156.

${ }^{28}$ Jennifer Lynn Stoever, The Sonic Colour Line: Race and the Cultural Politics of Listening (New York: New York University Press, 2016), 112.

${ }^{29}$ Sarah H. Bradford, Harriet: The Moses of her People (New York: Geo. R. Lockwood \& Son, 1886).

${ }^{30}$ Freeman's Journal, 30 September 1845.

${ }^{31}$ Glasgow Chronicle, 25 September 1835.

${ }^{32}$ Frederick Douglass, Life and Times of Frederick Douglass, Written By Himself [1892] in McKivigan, Douglass Papers, ser. 2, 3:185.

33 This wording was used in the Freeman's Journal, 30 September 1845; Dublin Evening Post, 30 September 1845; Dublin Weekly Register, 4 October 1845; and The Pilot, 1 October 1845. Other reports were equally matter-of-fact:
} 
As Douglass undoubtedly recognized, O'Connell's rhetorical flourish in Glasgow riffed on the oft-told story of how, during the revolution in colonial Saint-Domingue, the French general Étienne Laveaux claimed that the rebel leader Toussaint Louverture was the "black Spartacus" predicted by the Enlightenment philosophe Abbé Raynal two decades before. ${ }^{34}$ The story circulated widely in nineteenth-century abolitionist discourse, popularized by Marcus Rainsford in 1805. ${ }^{35}$ George Pitt's play Toussaint L'Ouverture, or the Black Spartacus was staged in London in June 1846, suggesting the parallel was still compelling, although there is no evidence that Douglass went to see it. ${ }^{36}$ In her historical romance The Hour and the Man (1839), Harriet Martineau speculated that Toussaint "heard these words and in his heart also were they glowing." 37 According to C. L. R. James, "He came in the end to believe in himself as the black Spartacus foretold by Raynal." 38 But Toussaint did not go so far as to adopt the designation applied to him by others. Douglass likewise resisted the temptation. He was happy to remind his audience at Conciliation Hall of O'Connell's famous invocation of a hypothetical Black counterpart. But to call himself "the Black O'Connell"- even as "playfully" as O'Connell may have applied it to him-would have trapped him within the terms of a contemporary whose agenda he must have realized was not always congruent with his own.

This would not have been Douglass's only reservation. If Raynal and Laveaux looked to ancient Rome for their model of Black leadership, O'Connell narcissistically looked in the mirror. And - if we are to trust Douglass's later recollection-O'Connell not only compared Douglass to himself, but bestowed on him his own name. This must have been more unsettling than flattering. It positions O'Connell as the figurative-or adoptive-father of Douglass, and the gesture is uncomfortably close to the convention of enslavers naming the enslaved after themselves - a mark of ownership, as well as of paternity, which was often the case, too.

Would Douglass never adopt a name like "the Black O'Connell," bestowed by another? The tragedian, Ira Aldridge - who was touring the West of Scotland when Douglass arrived in Glasgow in January 1846-did. In 1825 the London Times had dubbed him, sarcastically, "the African Roscius" (after the Roman actor, Quintus Roscius Gallus) in a way that was meant to suggest that he fell far short of the comparison. (A good example of a deliberately offensive use of antonomasia.) But Aldridge turned the nickname to his advantage and used it to advertise his shows, and even spun an increasingly elaborate and fictitious biography to fit. ${ }^{39}$

Douglass was presented with several opportunities to follow suit. In a newspaper report of one of his earliest speeches in Massachusetts, the writer "could not help thinking of Spartacus," specifically Edwin Forrest's performance in Robert Montgomery Bird's drama The Gladiator

\footnotetext{
"Mr O'Connell requested the meeting not to separate for a moment, as there was a person of the name of Mr. Douglas, one who had been a slave, and who would address them" (Waterford Chronicle, 1 October 1845; Tipperary Free Press, 1 October 1845); "Frederick Douglas, who was recently a slave in the United States, having been introduced to the meeting" (Dublin Evening Mail, 1 October 1845; Cork Examiner, 1 October 1845); "Mr O'Connell next introduced a black gentleman, named Douglas, who had been a slave" (London Standard, 1 October 1845; London Morning Herald, 1 October 1845).

34 [Louis] Dubroca, La vie de Toussaint Louverture (Paris: Dubroca, 1802), 16.

${ }_{35}$ Marcus Rainsford, An Historical Account of the Black Empire of Hayti (London: James Dundee, 1805), 247.

36 Jenna M. Gibbs, Performing the Temple of Liberty: Slavery, Theater, and Popular Culture in London and Philadelphia, 1760-1850 (Baltimore: Johns Hopkins University Press, 2014), 214-66.

${ }^{37}$ Harriet Martineau, The Hour and the Man, 3 vols. (London: Edward Moxon, 1841), 1:191.

${ }^{38}$ C. L. R. James, The Black Jacobins: Toussaint L'Ouverture and the San Domingo Revolution, rev. ed. (London: Allison \& Busby, 1980), 250.

${ }^{39}$ Bernth Lindfors, Ira Aldridge: The Early Years, 1807-33 (Rochester, N.Y.: University of Rochester Press, 2011), $83-85$.
} 
(1831), which premiered in New York in the wake of Nat Turner's insurrection in Virginia. ${ }^{40}$ In 1846 a reporter for the Manchester Examiner ventured to remark of Douglass: "He is tall, and of great muscular strength; indeed, he might serve as a model for a negro Hercules." ${ }^{41}$ Spartacus and Hercules were classical prototypes, polished by the centuries in a way the contentious O'Connell was not. But Douglass himself had no wish to take their names, perhaps partly because they were uncomfortably close to those like Caesar, Scipio, and Pompey, names commonly assigned by enslavers to mock the powerlessness of the enslaved rather than as a sign of respect. In any case, in 1845 Douglass already bore the name of an ancient forebear. He did not have to wait for a theatre critic, newspaper reporter, or political leader to make the first move.

\section{III}

After slipping out of Baltimore in 1838, Douglass changed his name several times to keep pursuers off his track. ${ }^{42}$ When he arrived in New Bedford, Massachusetts, a few months later, Nathan Johnson encouraged him to adopt the patronymic "Douglass" (after the hero of Walter Scott's Lady of the Lake) several years before he took to the public stage. In his account of the renaming in My Bondage and My Freedom (1855), Douglass generously compares Johnson to the character in the poem:

Considering the noble hospitality and manly character of Nathan Johnson, I have felt that he, better than I, illustrated the virtues of the great Scottish chief. Sure I am, that had any slave-catcher entered his domicile, with a view to molest any one of his household, he would have shown himself like him of the "stalwart hand." 43

But he must have seen parallels with himself, too. The couplet he quotes in part more fully reads: "Douglas of the stalwart hand / Was exiled from his native land." 44 Like the fugitive slave, James Douglas is an outlaw and an exile. At one point in the poem he is compared to a "hunted stag." 45 This must have had some resonance for the author of the 1845 Narrative who recounted his escape from "the hunters of men." 46

Later, he would be pleased to discover that he shared the name with another James Douglas, the legendary, ferocious commander who fought alongside Bruce at the Battle of Bannockburn (1314), commonly known as "the Black Douglas." Many Scots would have known of his exploits from Walter Scott's popular Tales of a Grandfather (1828-30), dashing stories from history designed to entertain his sick grandson. In his Tales, Scott suggests that the Black Douglas was socalled because of his "swarthy complexion" and "dark hair." ${ }^{77}$ But for his enemies, the epithet was less likely to refer to his appearance than to his ruthless cruelty. "You must know," writes Scott,

\footnotetext{
${ }^{40}$ Liberator, 3 December 1841.
}

${ }^{41}$ Manchester Examiner, 11 July 1846. In a private letter of 13 May 1847, James Alexander described Douglass as “a black Demosthenes” after seeing him the previous day. John Hall, ed., Forty Years' Familiar Letters of James W. Alexander, D.D., 2 vols (New York: Charles Scribner, 1860), 2:69.

42 Douglass, Narrative [1845], in Blassingame, McKivigan, and Hinks, Douglass Papers, ser. 2, 1:77.

${ }^{43}$ Frederick Douglass, My Bondage and My Freedom, in Blassingame, McKivigan, and Hinks, Douglass Papers, ser. 2, 2:197.

${ }^{44}$ Walter Scott, Lady of the Lake [1810], v, xxiv, in The Poetical Works of Sir Walter Scott, ed. J. Logie Robertson, 2 vols. (London: Oxford University Press, 1904), 259.

${ }^{45}$ Scott, Lady of the Lake, II, xxxvii, in Poetical Works, 229.

${ }^{46}$ Douglass, Narrative [1845], in Blassingame, McKivigan, and Hinks, Douglass Papers, ser. 2, 1:78.

${ }^{47}$ Walter Scott, Tales of a Grandfather, 6 vols. (Edinburgh, Scot.: Robert Cadell, 1836), 1:174. 
"that the name of Douglas had become so terrible to the English, that the women used to frighten their children with it, and say to them when they behave ill, that they 'would make the Black Douglas take them.' ",48

The whole line of Sir James's descendants were known as the Black Douglases, starting with William, the first earl of Douglas, whose son was killed by English forces commanded by Sir Henry "Hotspur" Percy at the Battle of Otterburn (1388). The third earl, Archibald the Grim, also fell foul of Percy, who took him prisoner at the Battle of Homildon Hill (1402), commemorated in a poem Douglass published in his newspaper in $1855 .{ }^{49}$ Forty years later it was not the English but King James II of Scotland who arranged - at the so-called "Black Dinner" - the murder of the sixth earl, concerned that the family was rivaling the Crown in wealth and military power. ${ }^{50}$

In Scotland, these legends were well known, and the briefest reference and a metaphorical wink to the audience was all the abolitionist needed to exploit the "heroic" and literary associations of his name. And from his hotel in Perth on 27 January 1846 in a letter to William Lloyd Garrison, he composed a response to the public accusation made by A.C.C. Thompson, a Marylander, alleging that his Narrative was a "catalogue of lies" and the Frederick Bailey he had known as a boy could not possibly have been its author:

I feel myself almost a new man-freedom has given me new life. I fancy you would scarcely know me. I think I have altered very much in my general appearance, and know that I have in my manners. You remember when I used to meet you on the road to St Michaels, or near Mr Covey's lane gate, I hardly dared to lift my head, and look up at you. If I should meet you now, amid the free hills of old Scotland, where the ancient "black Douglass" once met his foes, I presume I might summon sufficient fortitude to look you full in the face; and were you to attempt to make a slave of me, it is possible you might find me almost as disagreeable a subject, as was the Douglass to whom I have just referred. Of one thing, I am certain-you would see a great change in me! ${ }^{51}$

Spelling the name of James Douglas the way he spelled his own, whether intentional or not, reinforces the implication here that the abolitionist is - "playfully," no doubt - claiming common cause with an old and revered Scottish dynasty. He presents himself to Thompson as one who has acquired a "fortitude" akin to that of a medieval warlord. ${ }^{52}$

That the feudal Douglases were not only famous but famous for their violence, however, poses a problem to the abolitionist who at the time was still, for the most part, a dutiful advocate of Garrison's doctrine of non-resistance. The story of the Douglases is littered with acts of

\footnotetext{
${ }^{48}$ Scott, Tales of a Grandfather, 1:142.

${ }^{49}$ Luke Lichen, “A Lady’s Tear,” Frederick Douglass' Paper, 6 April 1855.

50 The best modern history of the family during this period is Michael Brown, The Black Douglases: War and Lordship in Late Medieval Scotland, 1300-1455 (East Linton, Scot.: Tuckwell Press, 1998). For further discussion of the representation of the Douglas dynasty in Scottish literature see Pettinger, Frederick Douglass and Scotland, $108-114$. ${ }^{51}$ Frederick Douglass to William Lloyd Garrison, Perth, 27 January 1846, in McKivigan, Douglass Papers, ser. 3, 1:85.

52 This move was perhaps the most audacious of what Tavia Nyong'o describes as a series of "perverse and unexpected affiliations" or "disidentifications" enacted by Douglass in relation to Scottish history and culture. Tavia Nyong'o, The Amalgamation Waltz: Race, Performance, and the Ruses of Memory (Minneapolis: University of Minnesota Press, 2009), 131. George Shepperson, who quotes the passage about the "ancient 'black Douglass" "at the head of his essay on "Frederick Douglass and Scotland," admits Douglass "seems to have found some peculiar fascination and destiny in the Scottish associations of his name" without pursuing the matter further. George Shepperson, "Frederick Douglass and Scotland," Journal of Negro History 38, no. 3 (1953): 307.
} 
unwarranted savagery arising from struggles with rival Scottish nobles as well as invading English armies. As he worked on his Tales, Scott wrote:

The morning was damp, dripping and unpleasant; so I even made a work of necessity, and set to the Tales like a dragon. I murdered McLellan of Bomby at Thrieve Castle; stabbed the Black Douglas in the town of Stirling; astonished King James before Roxburgh; and stifled the Earl of Mar in his bath in the Canongate. A wild world, my masters, this Scotland of ours must have been. ${ }^{53}$

With these events long past, Scott can relish the bloodshed as if he were writing fiction. One who could not appreciate this violent history was the pacifist Henry Clarke Wright, Douglass's fellow campaigner who had joined up with him in Perth. In his letters from the Scottish Borders two months later, Wright finds it impossible to withhold his solemn judgement of a different age: "It has been a golgotha and a field of blood," he wrote from Jedburgh, while in Berwick he is reminded of "Wallace, Bruce, Edward, Northumberland, and Douglass, and many other of the butchers and tigers of mankind." 54

As a nonresistant, Douglass might have wanted to avoid being identified with such butchers and tigers. And in January 1846, as I will show, we can see him wrestling with the moral and political ramifications of choosing such a violent man as a role model. Alternately pushing against the limits of moral suasion and retreating, sometimes within the space of a few lines, it is as if Douglass was rehearsing his eventual break with Garrison, perhaps without fully realizing it.

In his response to Thompson, in order to make the reversal of their relationship as dramatic as possible, Douglass contrasts their former encounters in Maryland, in which the young slave "hardly dared to lift my head, and look up at you," with a hypothetical one in Scotland, in which Thompson is the one quaking before a powerful man capable of awesome retribution should he be wronged. Some readers of the letter might have been reminded of the episode known bleakly as "Douglass's Larder," in which the Good Sir James recaptured his fortress from the English, "and, putting the garrison to the sword, mingled the mangled bodies with a large stock of provisions which the English had amassed, and set fire to the castle." ${ }^{55}$ But Douglass, who hints at a possible justification for ancient violence by implying that it was in the cause of freedom, can only refer to this threat euphemistically as "disagreeable." He may have chosen the word carefully to spare the

\footnotetext{
${ }^{53}$ Walter Scott, The Journal of Sir Walter Scott, 2 vols. (New York: Harper \& Brothers, 1891), 2:39 (entry for 29 September 1827).

${ }^{54}$ Henry Clarke Wright to William Lloyd Garrison, Jedburgh, 19 March 1846 and Berwick, 22 March 1846, Liberator, 1 May 1846. Nathaniel Rogers provided a vivid account of exploring Melrose Abbey with Garrison en route to Scotland after attending the World Anti-Slavery Convention in London in 1840. Nathaniel P. Rogers, "Ride into Edinburgh," in A Collection from the Newspaper Writings of Nathaniel Peabody Rogers (Concord, Mass.: John R. French, 1847), 113-15; see also James Mott, Three Months in Great Britain (Philadelphia: J. Miller M'Kim, 1841), 73; Lucretia Mott, Slavery and "The Woman Question": Lucretia Mott's Diary of Her Visit to Great Britain to Attend the World's Anti-Slavery Convention of 1840, ed. Frederick B. Tolles (Haverford, Pa.: Friends' Historical Association, 1952), 72-73. For later accounts by abolitionists of their visits to such historic Scottish sites see William Wells Brown, Three Years in Europe; or, Places I Have Seen and People I Have Met (London: Charles Gilpin, 1852), 186-93; Harriet Beecher Stowe, Sunny Memories of Foreign Lands, 2 vols. (Boston: Phillips, Sampson \& Co., 1854), 1:12868; Samuel Ringgold Ward, Autobiography of a Fugitive Negro: His Anti-Slavery Labours in the United States, Canada, \& England (London: John Snow, 1855), 344-47; Julia Griffiths, "Letters from the Old World-Number XXI," Frederick Douglass' Paper, 27 June 1856 and "Letters from the Old World-Number XXII," Frederick Douglass' Paper, 4 July 1856. For a useful discussion that bears on these accounts, see Elisa Tamarkin, "Black Anglophilia; or, the Sociability of Antislavery," American Literary History 14, no. 4 (2002): 444-78.

55 Walter Scott, The History of Scotland, 2 vols. (London: Longman, Rees, Orme, Brown, \& Green, 1830), 1:96.
} 
blushes of the Garrisonians, but, like many euphemisms, it may also represent a sly avowal that knows all too well what terrors lie behind it.

Two days later, in Dundee, the free hills of Scotland once more make their way into a letter, this time to Francis Jackson, an abolitionist colleague of Garrison's. Not intended for publication, as the letter from Perth was, it may have offered Douglass the opportunity to express himself more honestly, although he would still have been tailoring his views to match those of his addressee:

I am now as you will perceive by the date of this letter in old Scotland - almost every hill, river, mountain and lake of which has been made classic by the heroic deeds of her noble sons. Scarcely has a stream but what has been poured into song, or a hill that is not associated with some force and bloody conflict between liberty and slavery. I had a view the other day of what are called the Grampion mountains that divide east Scotland from the west. I was told that here ancient crowned heads use to meet, contend and struggle in deadly conflict for supremacy, causing those grand old hills to run blood, each warming cold steal in the others heart. ${ }^{56}$

In this passage, Douglass's namesake disappears into the more generic "noble sons," but their cause, at least initially, is defined as "heroic" and implicitly in defence of "liberty" against "slavery" (Douglass on this occasion finding it advantageous to deploy the term "slavery" metaphorically, to weld the cause of the "noble sons" to his own abolitionism, a usage he normally strongly criticized). The violence, though, is more openly acknowledged: blood runs freely in Douglass's prose here. At the same time, the noble cause becomes more ambiguous, less a struggle for freedom from foreign rule than a "deadly conflict for supremacy." Douglass seems to be admitting here that the foes of his illustrious forebears were not just the English invaders but rivals competing for personal power and wealth. Having gone much further than his earlier letter in recognizing what this ancient violence entailed, he now feels compelled to reflect on what it means for him to celebrate it:

My soul sickens at the thought yet I see in myself all those elements of character which were I to yield to their promptings might lead me to deeds as blood as those at which my soul now sickens, and from which I now turn with disgust and shame. Thank God liberty is no longer to be contended for and gained by instruments of death. A higher, a nobler a mightier than carnal weapon is placed into our hands — one which hurls defiance at all the improvements of carnal warfare. It is the righteous appeal to the understanding and the heart - with this we can withstand the most fiery of all the darts of perdition itself. I see that America is boasting of her naval, and military power-let her boast. She may build her walls and her forts, making them proof against ball and bomb. But while there is a single voice in her midst to charge home upon her the duty of emancipation neither her army, nor her navy can protect her from the knawing of a guilty conscience. ${ }^{57}$

Douglass here - with his reference to "carnal weapons" - echoes the defiantly pacifist language of Garrison's "Declaration of Sentiments."

\footnotetext{
${ }^{56}$ Frederick Douglass to Francis Jackson, Dundee, 29 January 1846, in McKivigan, Douglass Papers, ser. 3, 1:89.

${ }^{57}$ Douglass to Jackson, Dundee, 29 January 1846, in McKivigan, Douglass Papers, ser. 3, 1:89-90.

${ }^{58}$ William Lloyd Garrison, "Declaration of Sentiments," Liberator, 14 December 1833, which speaks of the need to reject "the use of all carnal weapons."
} 
misgivings seem to be cast aside. Douglass is pleased to stand before his audience at the Bell Street Chapel and recycle the phrases that had caused him such disgust and shame the night before in order to massage his listeners' patriotism. In that standard ritual of the touring performer, Douglass declares himself happy to be in "a land whose every hill has been made classic by heroic deeds performed by her noble sons - a land whose every brook and river carry the songs of freedom as they pass to the ocean - a land whose hills have nearly all been watered with blood in behalf of freedom." Although Douglass is quick to qualify the bloodshed as "heroic" and "in behalf of freedom," he risks blunting the force of his argument against the Free Church, which he condemns immediately afterwards for striking "hands in good Christian fellowship with men whose hands are full of blood." The blood of slavery and the blood of freedom are uncomfortably close together. ${ }^{60}$

A week later he was back in Glasgow, preparing the text of his Narrative for the second Irish edition, writing a new preface, and inserting his letter to Garrison (and its enclosed response to Thompson) as an appendix. His publisher in Dublin, Richard Webb, characteristically thought the insertion was "clever but swaggering."61 But Douglass clearly set much store by it, substantially revised the text for publication, and reworked several passages from it in speeches he made in Scotland in the weeks and months that followed. Here is how he refashions his invitation to Thompson to picture him as he is now:

I feel myself a new man. Freedom has given me a new life. The change wrought in me is truly amazing. If you should meet me now, you would scarcely know me. You know when I used to meet you near Covey's wood-gate, I hardly dared to look up at you. If I should meet you where I now am, amid the free hills of Old Scotland, where the ancient "Black Douglass" once met his foes, I presume I might summon sufficient fortitude to look you full in the face. It may be that, wearing the brave name which I have assumed, might lead me to deeds which would render our meeting not the most agreeable. Especially might this be the case, if you should attempt to enslave me. You would see a wonderful difference in me. ${ }^{62}$

No sentence survives unchanged. If the first version celebrates a "great change in me" (referred to once), the second twice takes it up an adjectival notch, intensifying it first as "amazing" and then as a "wonderful difference." Cautious qualifications ("almost" and "I fancy") and redundant phrases ("lift up my head") are deleted and a rather pedantic distinction between how certain he is of his alteration of "manners" as opposed to his "general appearance" is dropped, making his tone more assertive. But the revision also makes more of the way this "change" in Douglass is wrought by movement in space as well as the passage of time, marked by a "where" as well as a "when." "If I should meet you now" becomes "If I should meet you where I now am," emphasizing the symbolic importance of his location in "Old Scotland." And, as the passage builds to its climaxthe hypothetical encounter between the author and his adversary on Scottish ground, which symbolizes the new relation of power between them-Douglass's retaliation, previously rendered

\footnotetext{
${ }^{59}$ Blassingame, Douglass Papers, ser. 1, 1:148.

${ }^{60}$ Blassingame, Douglass Papers, ser. 1, 1:149.

${ }^{61}$ Richard Webb to Edmund Quincy, Dublin, 2 February 1846, in British and American Abolitionists, ed. Clare Taylor (Edinburgh, Scot.: Edinburgh University Press, 1974), 250.

62 Douglass, Narrative [1846], in Blassingame, McKivigan, and Hinks, Douglass Papers, ser. 2, 1:158-59.
} 
as "disagreeable" is amended to "not the most agreeable," a use of litotes that mischievously draws even more attention to the violence of the retribution he has in store for his opponent.

But perhaps the most significant revision is that here, the author of the Narrative, rather than simply comparing the power of his retaliation to that of the Black Douglas, implies that this power is somehow derived from the "brave name which I have assumed." A statement that at once reaffirms the appropriateness of the name he chose in New Bedford and allows him to lay claim to a fictive ancestry through which he has - supernaturally, as it were-inherited physical strength and courage. An "amazing" and "wonderful" change indeed, that, taking on an almost mythic quality, releases him from the trap of being no more than a copy of a flawed living politician. No wonder then that it was as a "Black Douglas" and not a "Black O'Connell" that he first declares his independence. 